\title{
Profesor Mirosław Kozik - wybitny poznański neuropatolog
}

\author{
Stawomir Michalak ${ }^{1,2}$ \\ IZakład Neurochemii i Neuropatologii Katedry Neurologii, Uniwersytet Medyczny im. K. Marcinkowskiego w Poznoniu \\ 2Zespół Bodowczo-Lezziczy Chorób Neuroimmunologiznych PAN w Poznaniu
}

Poznańska Klinika Neurologii od jej utworzenia w 1921 r. przez prof. Stefana Borowieckiego (18811937) poprzez okres kierownictwa prof. Anatola Dowżenki (1905-1976) do czasów wspótczesnych prowadzi działalność naukową, której ważnym elementem były badania neuropatologiczne. Profesor Anatol Dowżenko kierował zespołem neurologów, wśród których znaleźli się: prof. Mieczysław Wender, późniejszy kierownik Kliniki w latach 1963-1996, oraz prof. Mirosław Kozik (ryc. 1.).
Obaj wybitni naukowcy rozwinęli działalność naukową, wykorzystując najnowocześniejsze w ówczesnym czasie metody i techniki badawcze. Profesor Mieczysław Wender do dziś kontynuuje aktywnie badania nad patologią chorób neuroimmunologicznych.

Przedwczesna śmierć przerwała działalność naukową profesora Mirosława Kozika. W bieżącym roku mija czterdziesta rocznica jego powołania na stanowisko kierownika Samodzielnej Pracowni Patologii Układu Nerwowego i Narządów Zmysłów. Okazja ta stała się

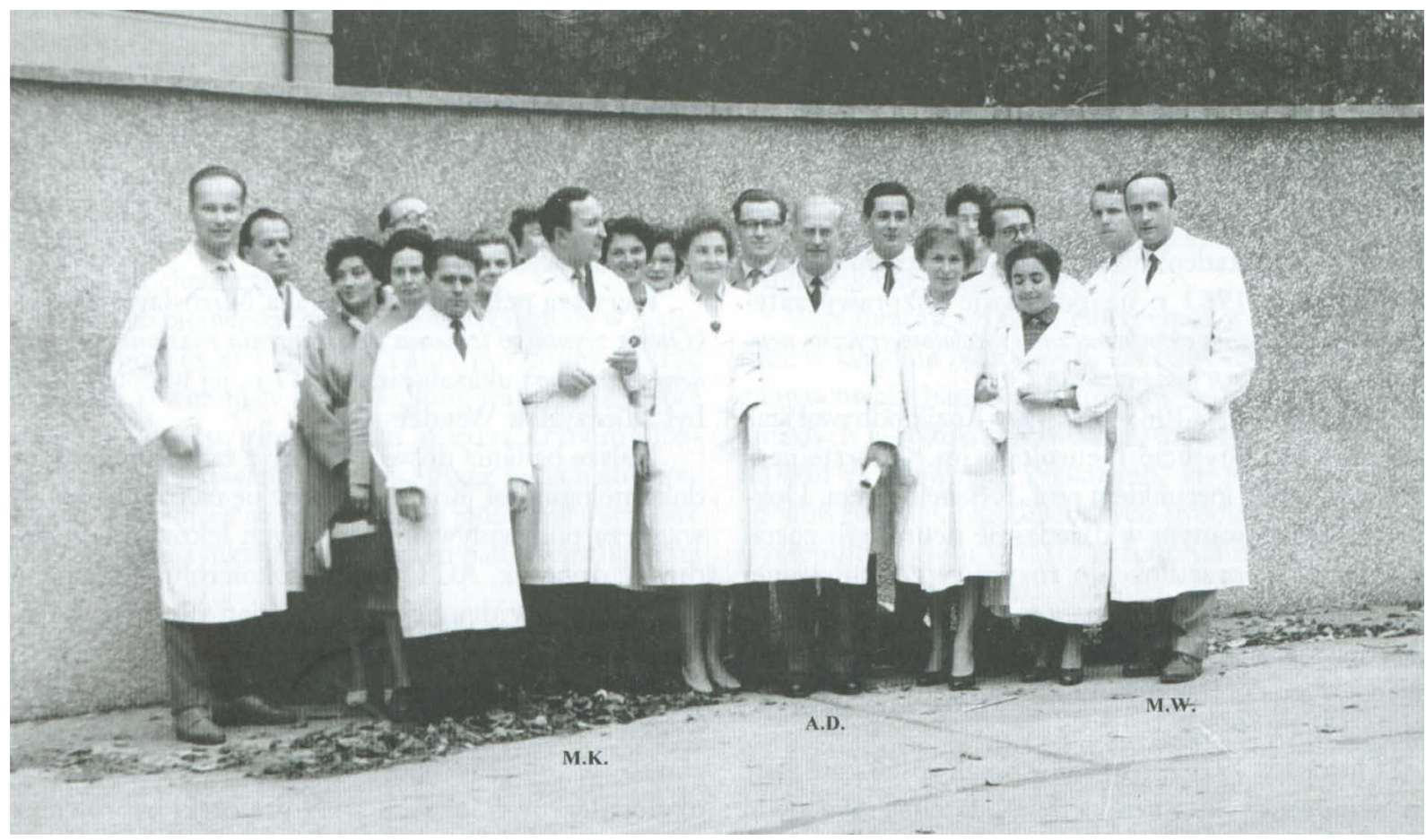

Ryc. 1. Zespół Kliniki Neurologii w Poznaniu pod kierownictwem prof. Anatola Dowzenki (A.D.). M.K. - prof. M. Kozik, M.W. - prof. M. Wender

Adres do korespondencji: Stowomir Michalak, Zakład Neurochemii i Neuropatologii, ul. Przybyszewskiego 49, 60-355 Poznań, faks +48618691444, e-mail: swami622@gmail.com 
inspiracją do przypomnienia sylwetki i działalności naukowej prof. Kozika.

Mirosław Bernard Kozik urodził się 19 sierpnia 1928 r. w Kościanie. Okres okupacji hitlerowskiej spędzil, w wyniku wysiedlenia, w Generalnej Guberni. Pracowal jako robotnik w fabryce samolotów w Mielcu od 1941 r. do czasu wkroczenia na te ziemie Armii Czerwonej. W 1944 r. rozpoczął pracę jako sanitariusz w radzieckim szpitalu frontowym. Po wojnie kontynuował naukę w Państwowym Gimnazjum i Liceum w Skwierzynie, gdzie w 1948 r. uzyskał świadectwo dojrzałości.

Studia na Wydziale Lekarskim, początkowo Uniwersytetu Poznańskiego, a potem Akademii Medycznej, odbywał w latach 1948-1953. Już jako student-wolontariusz podjął w 1949 r. pracę w Zakładzie Histologii Prawidłowej i Embriologii Uniwersytetu Poznańskiego, którą kontynuował po ukończeniu studiów. Następnie w latach 1954-1970 pracowat jako asystent, a później adiunkt $\mathrm{i}$ docent $\mathrm{w}$ Klinice Neurologii kierowanej początkowo przez prof. Anatola Dowżenkę, a potem prof. Mieczysława Wendera. Kolejne stopnie specjalizacji z neurologii Mirosław Kozik zdobywał odpowiednio w 1958 r. i 1961 r., a w 1974 r. z neuropatologii.

Stopień naukowy doktora medycyny Rada Wydziału Lekarskiego Akademii Medycznej w Poznaniu nadala mu 6 lutego 1963 r. na podstawie rozprawy zatytułowanej Badania cytochemiczne $i$ cytofotometryczne neuronu w krwotokach mózgowych.

W latach 1964-1965 Mirosław Kozik odbywał staż naukowy w Instytucie Neurologii im. Obersteinera w Wiedniu pod kierunkiem prof. F. Seitelbergera. Doktorem habilitowanym $\mathrm{w}$ dziedzinie neurologii został w 1969 r. po przedłożeniu rozprawy zatytułowanej Zmiany zwyrodnieniowe neuronu w swoietle badań doswiadczalnych. Minister Zdrowia i Opieki Społecznej mianował go docentem w Akademii Medycznej w Poznaniu 1 lipca $1970 \mathrm{r}$.

1 listopada 1970 r. Mirosław Kozik został powołany na stanowisko kierownika Samodzielnej Pracowni Patologii Układu Nerwowego i Narządów Zmysłów, którą następnie w 1978 r. przekształcono w Zakład Neuropatologii. W wyniku reorganizacji struktur Akademii Medycznej w Poznaniu Zakład Neuropatologii przeniesiono na Wydział Pielęgniarstwa, na którym utworzono również Klinikę Neurologii. Docent Mirosław Kozik został kierownikiem obu tych jednostek. Rada Państwa 5 października 1978 r. nadała mu tytuł naukowy profesora nadzwyczajnego nauk medycznych, a z dniem 1 czerwca $1979 \mathrm{r}$. Minister Zdrowia i Opieki Społecznej powolał go na stanowisko profesora nadzwyczajnego. W latach 1973-1978 prof. Kozik dzięki niezwykłemu zaangażowaniu doprowadzil do powstania nowej części zabudowań szpitalnych, w których zlokalizowano Zakład Neuropatologii. Budynek ten do dziś nazywany jest „Kozikówką".

W kadencji 1978-1980 Mirosław Kozik pełnił funkcję sekretarza naukowego Komisji Medycyny Klinicznej i Doświadczalnej PAN.

Przedwczesna śmierć 12 lipca 1983 r. po ciężkiej chorobie przerwała jego karierę zawodową i naukową. Dzieło, które pozostawił po sobie prof. Mirosław Kozik w postaci prac naukowych, rozdziałów w podręcznikach oraz wykształcenia personelu doświadczonego w metodach badań neuropatologicznych, pozostawiło trwały ślad w poznańskim środowisku.

W bazie PubMed do dzisiaj odnaleźć można 130 pozycji literatury autorstwa prof. Mirosława Kozika. Na jego dorobek składa się 185 publikacji pełnotekstowych drukowanych w czasopismach krajowych i zagranicznych oraz 159 doniesień przedstawionych na kongresach i zjazdach naukowych.

Pierwsza pelnotekstowa praca Mirosława Kozika (Ocena wyników leczenia stwardnienia rozsianego krwia hemolizowana) ukazała się w 1957 r., jej współautorem był Mieczysław Wender.

Dalsze badania doświadczalne z zakresu neuroendokrynologii prof. Kozika skupiały się na patologii podwzgórza pod wpływem rtęciowych leków moczopędnych, drgawek, ACTH i alfa-tokoferolu. Badania te prowadzone w drugiej dekadzie lat 50. dostarczyły dowodów na zaangażowanie jąderka w wytwarzanie neurohormonów (wówczas używano określenia „neurosekret") opartych na obserwacji Gomori-pozytywnych ziaren w obrębie jądra komórkowego oraz ich okołojąderkowej lokalizacji. Nowatorski był również wówczas pogląd Mirosława Kozika o braku odwrotnie proporcjonalnej zależności pomiędzy ilością neurohormonu a substancją Nissla. Wykazał on równiez, że transport neurohormonów z podwzgórza do przysadki wiązał się z pojawieniem się reakcji PAS-pozytywnej wskazującej na ich przemiany chemiczne. Ponadto zajmował się w tym okresie patologią neuronów w przebiegu chorób naczyniowych mózgu. 
Rozwój metod histochemicznych pozwolił Mirosławowi Kozikowi na podjęcie badań nad zaburzeniami lipidów komórek nerwowych w przebiegu udaru mózgu u ludzi oraz w modelach doświadczalnych u zwierząt. Kontynuował jednocześnie badania neuroendokrynologiczne dotyczące podwzgórza oraz osi podwzgórzeprzysadka. Ich wyniki wskazywały na nasilenie produkcji hormonu antydiuretycznego w modelach doświadczalnych drgawek oraz hipoglikemii poinsulinowej. Podkreślał on również znaczenie zaburzeń czynności podwzgórza po urazach czaszkowo-mózgowych.

W drugiej połowie lat 60 . prace Kozika skupiały się na zagadnieniu architektoniki histochemicznej mózgu. $\mathrm{Na}$ pierwszej konferencji Stowarzyszenia Neuropatologów Polskich w 1969 r. Mirosław Kozik przedstawił pracę Niektóre aspekty cytochemiczne schorzeń neuronalnych, za którą otrzymał doroczną nagrodę naukową.

Lata 70. dla Mirosława Kozika i kierowanego przez niego Zakładu rozpoczęły się wprowadzeniem najnowocześniejszych metod badawczych. Pierwszy w Polsce zastosował on mikrospektralną analizę laserową do badań skrawków tkankowych. Fakt ten został odnotowany nie tylko w czasopismach fachowych, ale także w prasie codziennej. Metoda laserowo-spektrograficzna pozwalała na obiektywną i ilościową ocenę aktywności enzymów (zwłaszcza fosfatazy kwaśnej) w skrawkach mózgowych i została wprowadzona do podręcznika metod histochemicznych.

Ponadto pionierskie zastosowanie tej metody w badaniu mózgów osób z chorobą Fàhra pozwoliło wykryć depozyty zawierające nie tylko jony wapnia, ale także zelaza, magnezu, glinu, cynku, miedzi, krzemu i fosforu. Niepublikowane wcześniej przez innych autorów wyniki wskazujące na udział innych jonów niz wapniowe stały się przyczynkiem do rozważań nad etiopatogenezą choroby Fahra.

Badania prowadzone nad zaburzeniami metabolicznymi towarzyszącymi zwyrodnieniu neuronu zaowocowały opracowaniem przez Mirosława Kozika autorskiej klasyfikacji zmian neurodegeneracyjnych. Postulowat on, by w ocenie procesów neurodegeneracyjnych uwzględniać nie tylko ich wykładniki morfologiczne, ale także właściwości metabolizmu komórek nerwowych w różnych stadiach rozwijającej się patologii. Wśród podnoszonych w tych ramach rozważań poznański neuropatolog zwracał uwagę na odrębności mechanizmów związanych ze zmianami homogenizacyjnymi obserwowanymi w komórkach Purkinjego, a niedokrwiennymi w neuronach. Metodami histoenzymatycznymi wykazał on, że w komórkach Purkinjego zmianom homogenizacyjnym towarzyszy pojawienie się aktywności dehydrogenazy b-hydroksymaślanu, dehydrogenazy bursztynianowej i NADP-diaforazy oraz pobudzenie aktywności NAD-diaforazy i dehydrogenazy glukozo-6-fosforanu. Takich zaburzeń nie obserwuje się $\mathrm{w}$ przebiegu zmian niedokrwiennych $\mathrm{w}$ neuronach.

Prowadzone przez Mirosława Kozika badania skupiały się również wokół procesu mielinizacji i jego zaburzeń w rozwoju ontogenetycznym oraz pod wpływem czynników egzogennych, ze szczególnym uwzględnieniem promieniowania jonizującego oraz metali ciężkich. Prace te zaowocowały poglądem Mirosława Kozika wskazującym na zwiększenie aktywności enzymatycznej oligodendrogleju jako wyrazu pobudzenia jego aktywności biologicznej w modelach doświadczalnych chorób demielinizacyjnych oraz $\mathrm{w}$ przebiegu stwardnienia rozsianego. Stanowisko to było w opozycji do hipotez o znaczeniu pierwotnego zaburzenia czynności oligodendrogleju w procesie demielinizacji.

Wykorzystując znakowane izotopami aminokwasy oraz metody autoradiograficzne, Mirosław Kozik podjął badania nad metabolizmem białek w gleju oraz jego znaczeniem dla demielinizacji. Pozwolity one wysunąć wniosek o odrębności przemian białek w komórkach glejowych w zależności od ich lokalizacji. Stosowane konsekwentnie metody histochemiczne uzupełnit on o mikroskopię elektronową.

Wspólpraca $\mathrm{z}$ prof. Seitelbergerem, w którego Instytucie w Wiedniu Mirosław Kozik odbywał staż naukowy, zaowocowała badaniami lipidów w mózgach dzieci zmarłych w wyniku pierwotnej patologii ośrodkowego układu nerwowego. Wykazano, że w przypadkach zgonów przed 4. tygodniem życia gromadzenie lipidów występuje w gleju w fazie przedmielinizacyjnej oraz perycytach, natomiast później depozyty lipidów i obładowane lipidami makrofagi obserwowano wokół drobnych naczyń zylnych i tętniczych, zwłaszcza w istocie białej i korze mózgowej. Zmiany te były niezależne od występowania obrzęku mózgu oraz pierwotnej patologii ośrodkowego układu nerwowego.

W ostatniej fazie swojej działalności naukowej prof. Kozik zajmowal się wpływem związków neurotoksycznych (środki ochrony roślin, metale ciężkie, leki) na układ nerwowy. Znaczna część tych prac - analizująca zarówno morfologię, jak i histochemię ośrodkowego układu nerwowego - poświęcona byla wpływowi rtęci i winkrystyny i publikowana w zagranicznych czasopismach.

Badania te prof. Kozik prowadził z pełną świadomością ich poznawczego oraz praktycznego znaczenia, 
podkreślając często znaczenie czynników egzogennych dla patologii układu nerwowego.

Przywołując w 40-lecie objęcia kierownictwa poznańskiego ośrodka neuropatologicznego przez prof. Mirosława Kozika jego najważniejsze dokonania naukowe, można dostrzec nawet $\mathrm{z}$ perspektywy minionego czasu ich pionierskie aspekty i znaczenie dla rozwoju neuropatologii.

\section{Pismiennictwo}

1. Kozik M.B., Znamierowska-Kozik M. A case of the acinous form of meningeal cysticercosis. Neurol Neurochir Pol 1984; 18 : 171-173.

2. Pietrzak M., Kozik M.B. The influence of the antimitotic drug CCNU on the neurosecretion of rat hypothalamo-hypophyseal system. Folia Histochem Cytobiol 1985; 23: 27-32.

3. Kozik M., Miętkiewski K. Badania histochemiczne nad jądrem nadwzrokowym i przykomorowym u kota. Endokrynol Pol 1959; 10: 1-6.

4. Kozik M., Kulczycki J. Laser-spectrographic analysis of the cation content in Fahr's syndrome. Arch Psychiatr Nervenkr 1978; 225: 135-142.

5. Kozik M. Histochemistry of Purkinje cells in experimental homogenization necrosis. Pathol Eur 1969; 4: 122-137.

6. Jellinger K., Seitelberger F, Kozik M. Perivascular accumulation of lipids in the infant human brain. Acta Neuropathol 1971; 19: 331-342.

7. Kozik M.B., Wigowska-Sowińska J. Changes in the activity of some hydrolases of the brain after the administration of methoxyethylmercuric chloride. Taxicol Appl Pharmacol 1980; 53: 122-133.

8. Kozik M.B., Szczech J. Histoenzymatic and morphometric changes occurring in nerve cells of gyrus cinguli following treatment of young rats with vincristine. Exp Pathol 1983; 24: 243-252.

9. Kozik M., Pioch E. Oponiak podczaszkowy przebiegający pod postacią zespołu Villareta. Neurol Neurochir Psychiatr Pol 1958; 8: 487-492.

10. Kulczycki J., Kozik M., Mossakowski M. Unusual calcifications in a monkey's brain. Acta Neuropathol $1981 ; 7: 59-60$. 